\title{
Reactivity of Microcrystalline Cellulose with Methyltrimethoxysilane and 3-(2-Aminoethylamino) propyltrimethoxysilanes
}

\author{
Przemysław Pietras, ${ }^{1,{ }^{*}}$ Hieronim Maciejewski ${ }^{1,2}$ and Bartłomiej Mazela ${ }^{3}$ \\ ${ }^{1}$ Adam Mickiewicz University Foundation, Poznań Science and Technology Park, Rubież 46, 61-612 Poznań, Poland \\ ${ }^{2}$ Faculty of Chemistry, Adam Mickiewicz University, Uniwersytetu Poznańskiego 8, 61-614 Poznań, Poland \\ ${ }^{3}$ Poznań University of Life Sciences, Institute of Wood Chemical Technology, Faculty of Wood Technology, Wojska Polskiego \\ 28, 60-637 Poznań, Poland \\ ${ }^{*}$ Corresponding author: E-mail: przemyslaw.pietras@ppnt.poznan.pl
}

Received: 03-25-2021

\begin{abstract}
In the presented research, two trialkoxysilanes were used to investigate their reactivity with microcrystalline cellulose (MCC) applied as a model material. As a continuation of the previous study, the research aimed at evaluation of the durability and potential reversibility of the silane treatment. Two different solvents and a mixture thereof were used for cellulose modification. The influence of amino group/pH, an excess of silanes and re-soaking with water on binding with cellulose was examined. The results obtained confirm that both selected silanes can effectively modify MCC. However, the treatment with 3-(2-aminoethylamino)propyltrimethoxysilane occurred more effective than with Methyltrimethoxysilane due to the presence of amino groups. Among the three tested solvents, the most effective was pure water. In contrast, the use of ethanol and a mixture of ethanol and water gave significantly worse results. Summarising, the presented research clearly shows how important the type of the functional group in alkoxysilanes is for its chemical reactivity with natural polymers, which is crucial for their application in waterlogged wood conservation.
\end{abstract}

Keywords: Cellulose, alkoxysilane, silane modification, microcrystalline cellulose

\section{Introduction}

Polymer-based materials play a significant role in modern industry. However, due to the depletion of fossil fuels, increasing health concerns, as well as heightened environmental awareness triggered by anthropogenic climate change, more emphasis is currently placed on developing environmentally friendly bio-based products. ${ }^{1,2}$

As renewable plant raw materials, natural polymers are an attractive alternative to synthetic petroleum-based supplies, that comply with principles of green chemistry, ecology, and sustainability. ${ }^{2,3}$ Potentially limitless susceptibility of natural fibres to various modifications enhancing their performance characteristics makes them perfect materials of the future. ${ }^{4,5}$

Cellulose is one of the most commonly employed natural polymers for many industrial purposes. ${ }^{6,7}$ Among others, it is widely applied as a reinforcement for polymeric hydrogels, aerogels, and composites. ${ }^{8-10}$ One of the forms of cellulose used i.a. as reinforcing agents are microcrystalline cellulose (MCC) or cellulose nanocrystals (CNCs), ${ }^{2,8,11-13}$ The main advantages of MCC and CNCs are their excellent mechanical properties (high strength and stiffness) along with their low weight, large surface area, biodegradability and renewability. ${ }^{14,15}$ However, some shortcomings, such as moisture absorption, susceptibility to high temperature or incompatibility with most polymeric matrices significantly limit the possibility of employing cellulose crystals for specific applications. ${ }^{15,16}$ Therefore, a variety of modifications has been recently tested to overcome these disadvantages. ${ }^{17,18}$

One of the solutions to enhance the performance of different forms of cellulose and override the problems concerning i.a. divergences between the polar and hydrophilic nature of cellulose and non-polar and hydrophobic character of a synthetic polymer matrix is creating organic-inorganic hybrids. ${ }^{19} \mathrm{~A}$ sol-gel technique is one of the significant 
methods to obtain this, and due to the specific chemical structure and the resulting reactivity, silicate systems (in particular trialkoxysilanes) became the most extensively studied among all compositions used in this technique. ${ }^{20,21}$

Organotrialkoxysilanes are the most common silicon derivatives. They are bifunctional molecules that contain both readily hydrolysable alkoxy groups and an organic functional group which determines their specific features. In the presence of water, alkoxy groups can hydrolyse and react with hydroxyl groups present on the surface of natural fibres forming siloxy bonds (Si-O-C). Simultaneously, they can also react with other silane particles forming more stable Si-O-Si bonds. ${ }^{22,23}$ The series of hydrolysis and condensation reactions is called the sol-gel process, and it results in the formation of a spatial network consisting of polysiloxane and natural polymers. ${ }^{24,25}$

Silanes have been widely used as coupling agents and surface modifiers i.e. for cellulose and other lignocellulosic materials. ${ }^{26-30}$ The silane modification proved to be effective in improving mechanical properties and fire performance of composites containing modified materials, reducing the hydrophilic character of the modified fibres, and limiting their susceptibility to biodegradation by fungi. $^{22}$ It is also efficient in facilitating dispersity of natural polymers with synthetic matrix and making them more compatible with human-made polymers. ${ }^{31-37}$ Silane modification can be widely applied not only to natural fibres but also i.e. metals, pigments, glass and others. Such modifications provide new or improved functionalities of silane treated material. ${ }^{38-41}$

The unique structure and the resulting reactivity of organosilicons make them also useful in the conservation of wooden artefacts. The results of our previous study proved the effectiveness of some organosilicon compounds (including methyltrimethoxysilane and 3-(2-aminoethylamino)propyltrimethoxysilane) in the stabilisation of waterlogged archaeological wood. ${ }^{42}$ However, the mechanism behind the dimensional stabilisation remains unclear, as well as issues related to durability and potential reversibility of the treatment that are important from the conservation perspective. Hence the concept of research presented herewith.

The proposed hypothesis assumes that silanes can form chemical bonds with the cell wall polymers (including cellulose) via alkoxy groups that results in reinforcement of the degraded cell wall leading to wood dimensional stabilisation. Moreover, due to the low chemical stability of alkoxy bonds, the interactions between silanes and cellulose are presumably reversible. Thus silane treatment under particular conditions (i.e. presence of water) could turn out to be impermanent. It is also assumed that the reactivity of particular alkoxysilanes with cellulose differs depending on the type of organofunctional group present in their molecules.

Given the above, the presented research aimed to investigate the reactivity of two trialkoxysilanes differing in the type of an organofunctional group (methyltrimethoxysilane and 3-(2-aminoethylamino)propyltrimethoxysilane) with microcrystalline cellulose used as a model material, which has not been studied before. Two different solvents and a mixture thereof were used for microcrystalline cellulose modification. The influence of the presence of $\mathrm{pH}$, excess of silane and re-soaking with water on binding stability with cellulose was examined.

\section{Materials and Methods}

\section{1. Materials}

Microcrystalline cellulose (MCC) and ethylenediamine were purchased at Sigma-Aldrich, ethanol (99.8\%) was purchased at P.O.CH. and used as received. methyltrimethoxysilane (MTMS) and 3-(2-aminoethylamino)propyltrimethoxysilane (AEAPTMS) were synthesised in Poznan Science and Technology Park.

\section{2. Methods}

\section{2. 3. Modification of Microcrystalline Cellulose \\ Influence of the solvent/water content}

Three different solvents were tested in the experiment:

- water,

- $99.8 \%$ ethanol,

- a mixture of ethanol and water $(3: 1, \mathrm{v} / \mathrm{v})$.

$0.5 \mathrm{~g}$ of MCC and $10 \mathrm{~g}$ of a particular solvent was placed in a beaker and stirred vigorously. After obtaining an MCC suspension, $0.5 \mathrm{~g}$ (or $3 \mathrm{~g}$ in the experiment with the excess of silanes, the details are described below) of an appropriate silane was added and stirred briskly for 2 hours. Microcrystalline cellulose was treated with MTMS and AEAPTMS in an MCC:silane mass ratio of 1:1 and 1:6, respectively. Unmodified MCC was suspended only in the appropriate solvent for 2 hours. The unmodified and modified MCC was then filtered off without additional washing and air-dried for 72 hours.

Air-dried MCC samples still contain physically bound water which can influence the results of an infrared spectroscopy analysis that was performed to assess the effectiveness of the silane treatment (the measurement of the number of hydroxyl groups - the details are described below in the Infrared spectroscopy section). Moreover, the presence of particular functional groups in modified MCC, originating in the silanes applied, can also increase the amount of bound water, altering the results of the spectroscopy measurements. Therefore, to clarify the actual amount of hydroxyl groups in unmodified MCC, a batch of MCC sample was oven-dried at $120^{\circ} \mathrm{C}$ for $24 \mathrm{~h}$, cooled down to room temperature and analysed using an FT-IR technique. Then the oven-dried MCC was divided into two parts, and modification with silanes was performed 
according to the above-described procedure. After modification, the samples were air-dried for $72 \mathrm{~h}$, and then oven-dried at $120^{\circ} \mathrm{C}$ for $24 \mathrm{~h}$, cooled-down and analysed.

\section{Influence of $p H$}

The modification was carried out as described above, using water as a solvent. Before adding an MTMS silane, $\mathrm{pH}$ of cellulose suspension was adjusted to the desired value of 10.2 (it was a $\mathrm{pH}$ value of the AEAPTMS solution applied for MCC modification) by the addition of ethylenediamine (EDA). Modified and unmodified MCC sample were filtered off without additional washing and air-dried.

\section{Influence of re-soaking in water}

The modification process was conducted following the procedure mentioned above (in a paragraph Influence of the solvent/water content) using water as a solvent. Then, after $48 \mathrm{~h}$ of air-drying, part of the samples was placed in distilled water and stirred for 10 minutes (re-soaking). In the next step, samples were filtered off and air-dried.

All the obtained cellulose-silane composites are presented in Table 1.

\section{Infrared spectroscopy}

All the modification reactions were controlled using Fourier Transform Infrared Spectroscopy (FT-IR). Infrared spectra for particular dried samples were recorded on a Bruker Tensor 27 FT-IR Spectrometer equipped with a SPECAC Golden Gate diamond ATR unit with $2 \mathrm{~cm}^{-1}$ resolution in the $4000-600 \mathrm{~cm}^{-1}$ absorbance range. Sixteen scans were collected for each spectrum. The spectra were baseline corrected.

Since modification with silanes involves the chemical reaction of hydroxyl groups present on the MCC surface with hydrolysed silane alkoxy groups, it is expected to observe a decrease in the number of free hydroxyls in
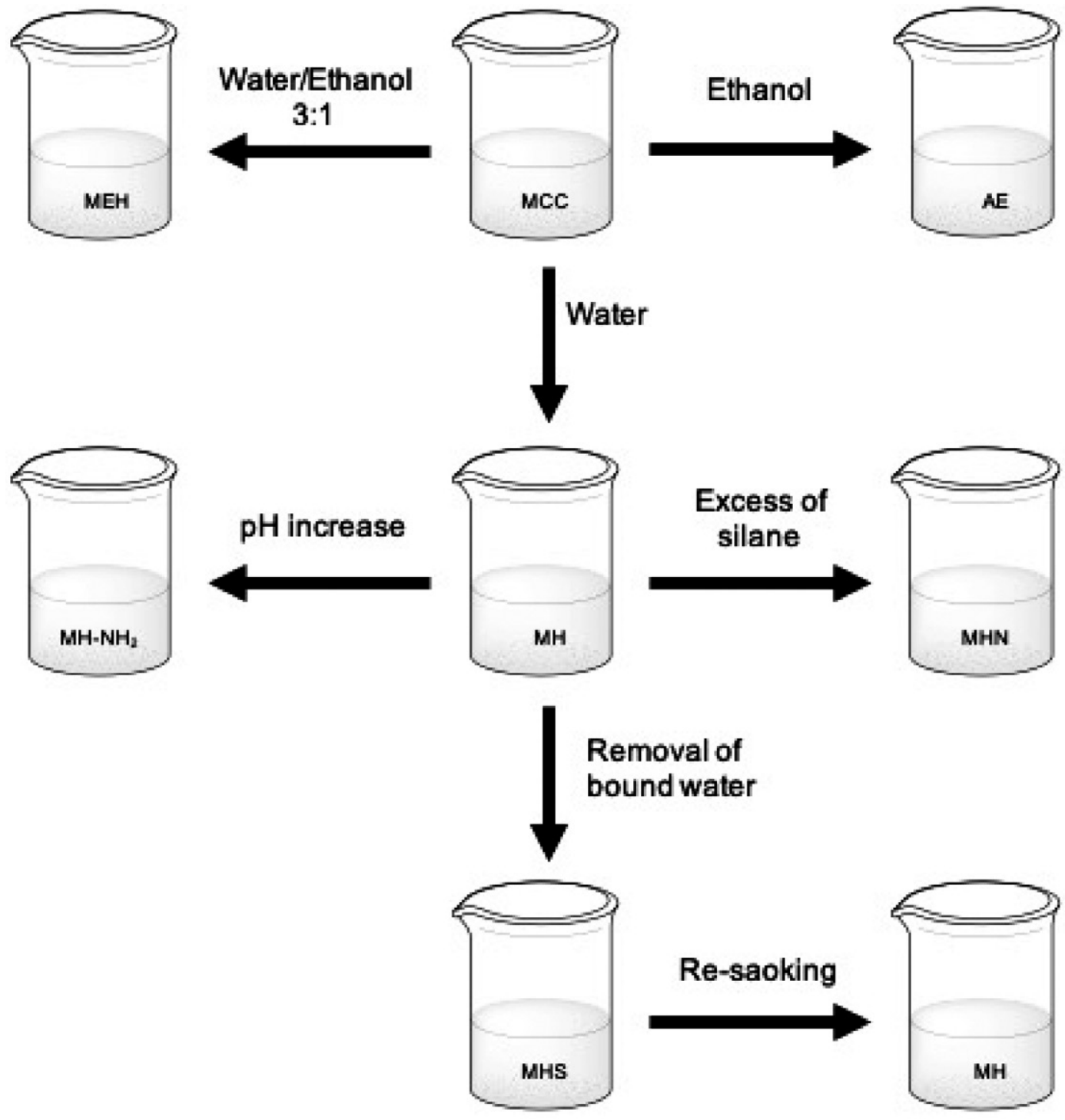

Fig. 1 Flowchart of chemical modification of MCC 
Table 1. Composition of obtained MCC samples

\begin{tabular}{|c|c|c|c|c|}
\hline Sample code & silane Used & $\begin{array}{l}\text { silane to cellulose } \\
\text { Ratio }(w / w)\end{array}$ & Solvent & Additional information \\
\hline $\mathrm{MH}$ & MTMS & $1: 1$ & Water & \\
\hline $\mathrm{AH}$ & AEAPTMS & $1: 1$ & Water & \\
\hline $\mathrm{MCCH}$ & & & Water & \\
\hline $\mathrm{ME}$ & MTMS & $1: 1$ & Ethanol & \\
\hline $\mathrm{AE}$ & AEAPTMS & $1: 1$ & Ethanol & \\
\hline MCCE & & & Ethanol & \\
\hline $\mathrm{MEH}$ & MTMS & $1: 1$ & Water:Ethanol 1:3 & \\
\hline $\mathrm{AEH}$ & AEAPTMS & $1: 1$ & Water:Ethanol 1:3 & \\
\hline MCCEH & & & Water & \\
\hline $\mathrm{MHN}$ & MTMS & $6: 1$ & Water & \\
\hline AHN & AEAPTMS & $6: 1$ & Water & \\
\hline MCCS & & & & Dried at $120^{\circ} \mathrm{C}$ for $24 \mathrm{~h}$ \\
\hline MHS & MTMS & $1: 1$ & Water & Dried at $120^{\circ} \mathrm{C}$ for $24 \mathrm{~h}$ \\
\hline AHS & AEAPTMS & $1: 1$ & Water & Dried at $120^{\circ} \mathrm{C}$ for $24 \mathrm{~h}$ \\
\hline $\mathrm{MH}-\mathrm{NH}_{2}$ & MTMS & $1: 1$ & Water & $\mathrm{pH}$ adjusted to 10.2 \\
\hline $\mathrm{MCCH}-\mathrm{NH}_{2}$ & & & Water & $\mathrm{pH}$ adjusted to 10.2 \\
\hline
\end{tabular}

modified MCC. Thus, to evaluate the effectiveness of the treatment, the hydroxyl content for unmodified and modified MCC was estimated by comparing the relative peak area of the absorption peak at $3300 \mathrm{~cm}^{-1}$ assigned to hydroxyl groups. The hydroxyl peak area (HPA) within the range of $3650-3000 \mathrm{~cm}^{-1}$ was calculated and expressed in arbitrary units (a.u.).

\section{Results and Discussion}

According to literature, the surface treatment of cellulose can be carried out with a silane solution in a commonly used concertation rate from 0.5 to $5 \%$ by weight. Such conditions offer several advantages: a) an increase in silane solubilisation in the medium, b) better control of the substrate film thickness on the surface, c) more uniform

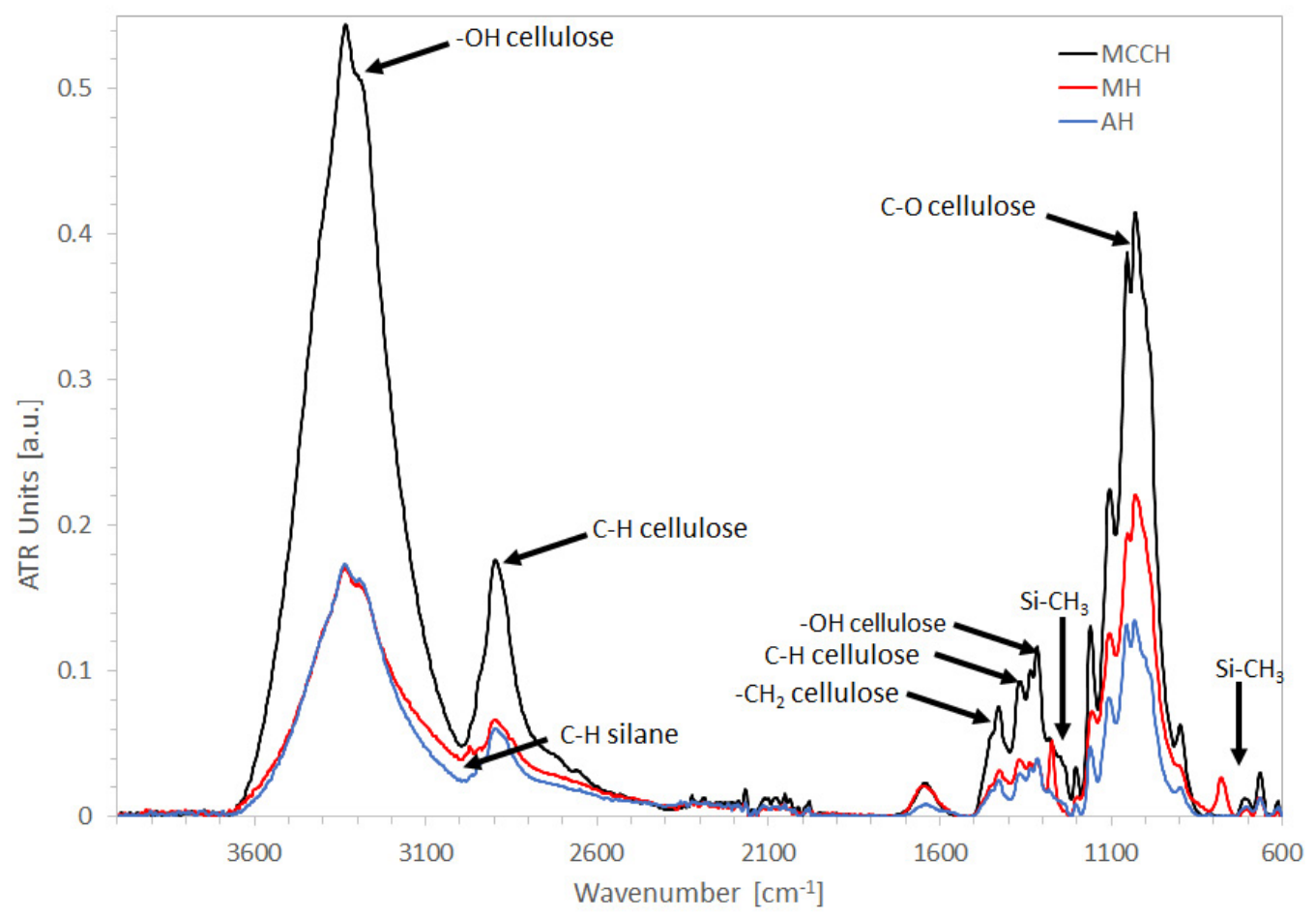

Fig. 2 FT-IR spectra of $\mathrm{MCCH}, \mathrm{MH}$ and $\mathrm{AH}$ 
coverage of the surface. The water-induced stepwise hydrolysis of the silane results in the formation of the corresponding silanols, which promotes the silane adsorption onto hydroxyl-rich substrates through hydrogen bonding. After solvent evaporation, the residual silanol groups may undergo a further condensation with the substrate hydroxyl groups. Moreover, they can also undergo self-condensation to form a polysiloxane network on the surface. Continued condensation leads to the formation of a gel-like network, which precipitates in the form of colloidal particles. Hydrolysis and condensation of the silanol groups are affected by the structure of the organic group of the silane and by the solvent characteristics $(\mathrm{pH}$, temperature, amount of water, concentration). ${ }^{48-49}$ Therefore, a set of different experiments were performed to investigate the effect of type of the solvent, amount of a silane applied, $\mathrm{pH}$ and substrate re-soaking in the water on the reactivity of the selected silanes with MCC. The modification process was controlled using Fourier Transform Infrared Spectroscopy (FT-IR). Infrared spectra of untreated and silane-treated samples are presented in Figure 2.

Natural polymers and materials based on them form a complex network whose characteristics at the molecular level are often complicated. The intricacy of the chemicals contained in the material reflects in the variability of the functional groups present, which hinders interpretation of their infrared spectra.

In the FT-IR spectra of untreated and treated MCC (Figure 2), bands specific to cellulose can be observed, i.e. at $3380(-\mathrm{OH}), 2730(\mathrm{C}-\mathrm{H}), 1427\left(-\mathrm{CH}_{2}\right), 1370(\mathrm{C}-\mathrm{H})$ and $1315 \mathrm{~cm}^{-1}(-\mathrm{OH})$, as well as at 1100,1050 and $1030 \mathrm{~cm}^{-1}$ (attributed to the stretching vibrations of C-O). ${ }^{46}$ They are characterised by a high absorbance in untreated $\mathrm{MCCH}$, while in treated $\mathrm{MH}$ and $\mathrm{AH}$ samples they are significantly reduced. Bands characteristic for silica are not visible in the spectra obtained, which can suggest that microcrystalline cellulose was not coated by silica but chemically modified by silanes. The band at $2960 \mathrm{~cm}^{-1}$ assigned for stretching vibrations of $\mathrm{C}-\mathrm{H}$ and bands at 1260 and $802 \mathrm{~cm}^{-1}$ attributed to the vibrations of $\mathrm{Si}-\mathrm{CH}_{3}$, that are present in the $\mathrm{MH}$, indicate the formation of a chemical bond between MTMS and MCC. ${ }^{47}$ Unfortunately, bands that are specific to amino silane (particularly to $-\mathrm{NH}_{2}$ ) are overlapped with bands characteristic for cellulose (especially $-\mathrm{OH}$ ), thus hardly visible. However, when comparing spectra of $\mathrm{MCCH}$ and AH samples with pure AEAPTMS used for modification (Figure 3), a change in the shape of the band at 1640 $\mathrm{cm}^{-1}$ attributed to the presence of water can be observed. Comparison of normalised $\mathrm{AH}$ and $\mathrm{MCCH}$ spectra highlights differences between them in this region. Much broader band in the $\mathrm{AH}$ spectrum seems to consist of two overlapping bands: a band at $1640 \mathrm{~cm}^{-1}$ and a band specific to AEAPTMS, which indicates the presence of amino silane in the modified AH sample.

\section{1. Influence of the Solvent/water Content on Silane Reactivity}

\section{1. Impregnation in Different Solvents}

The influence of the type and composition of the applied solvent on the MCC modification efficiency with

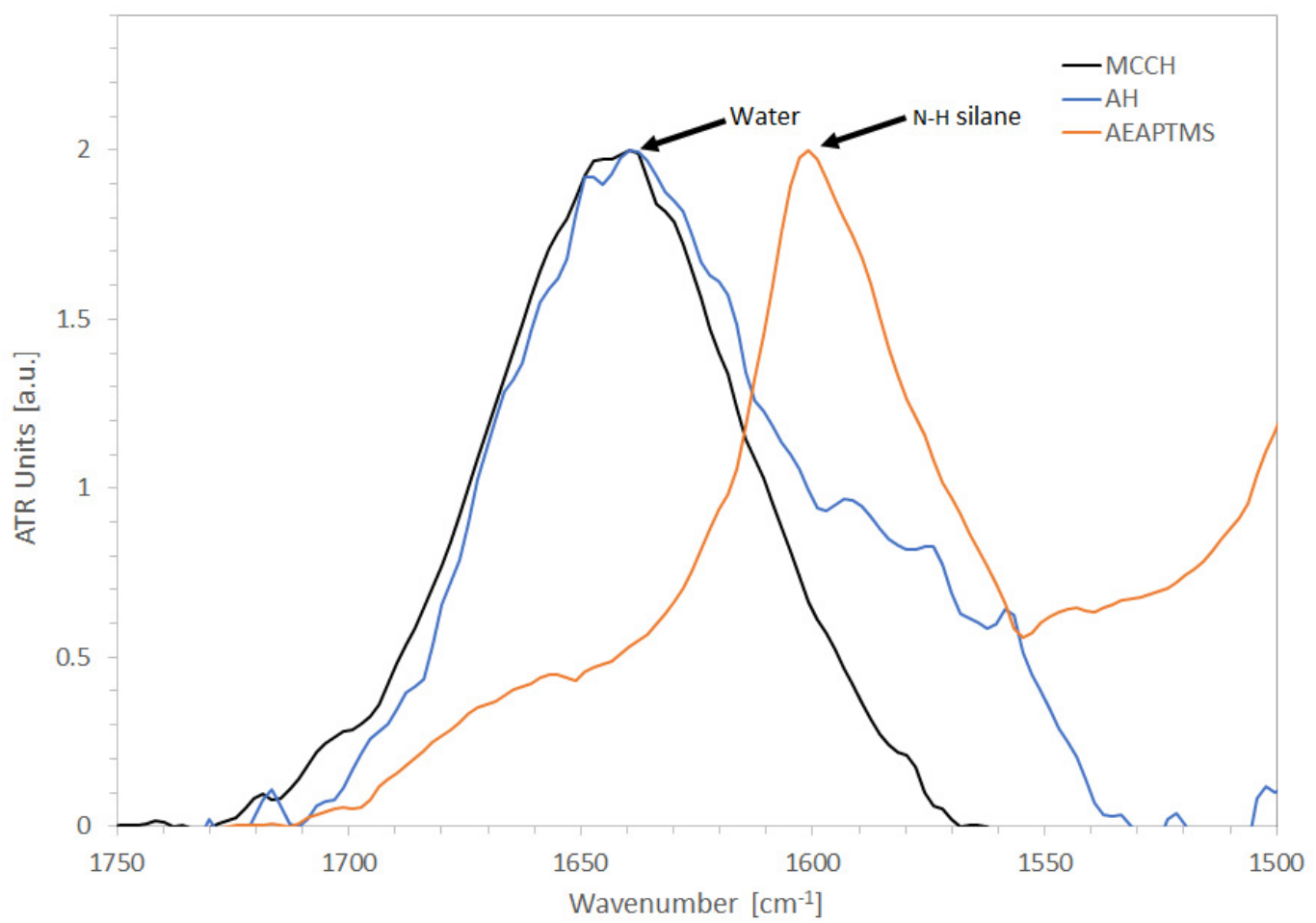

Fig. 3 FT-IR spectra of MCCH, AH and AEAPTMS 
silanes (mass ratio 1:1) was investigated using water, ethanol and a mixture thereof (1:3). The changes in HPAs are presented on a graph in Figure 4 . The graph starts only after $5 \mathrm{~h}$ of samples air-drying because directly after treatment the obtained infrared spectra were dominated by the bands specific to the particular solvents, and the measurement of the HPA was meaningless.

Starting with MCC treated with the use of water as a solvent. As it is clear from Figure 4, for all the samples, HPA decreases upon drying. The high initial HPA values result from the adsorption of water used as a solvent by the samples. They are similar for untreated $\mathrm{MCCH}$ and AEAPTMS-treated AH, and slightly lower from MTMS-treated MH. The observed difference between $\mathrm{MCCH}$ and $\mathrm{MH}$ can be explained by chemical modification of MH with silane, which limits the number of hydroxyl groups on its surface and increases its hydrophobicity thus reducing the number of water molecules interacting with MCC. AH, however, despite its chemical modification, has a stronger affinity to water due to the hydrophilic character of amino groups from the silane applied, which is visible as higher HPA, almost equal to highly hydrophilic unmodified $\mathrm{MCCH}$. The different character of the functional groups of the used silanes also reflects in the rate of drying of particular samples. More hydrophilic AH dries slower than MH. The final HPA values after $72 \mathrm{~h}$ of air-drying for both treated samples are similar (about 40 a.u.). However, they are only almost half a size of HPA for unmodified cellulose (about 90 a.u.), which confirms their effective modification with silanes. However, since there is still bound water present in the air-dried cellulose samples (and it is included in the HPA value), the comparison of the effectiveness between particular silanes is unjustified.
An entirely different trend can be seen for samples suspended in ethanol (ME, AE and MCCE in Figure 4). First of all, the initial HPA values are significantly lower in comparison with samples suspended in water: about 3 times for unmodified MCC, about 2.5 times for MTMS-treated and more than 5 times for AEAPTMS-treated, respectively. It results from considerably lower water content in the solvent (only about $0.2 \%$ in comparison with the former 100\%) thus the lower total number of hydroxyl groups present.

Interestingly, for samples suspended in ethanol, the HPAs after $5 \mathrm{~h}$ of air-drying are the lowest, and they increase and then decrease slightly upon drying. This phenomenon can suggest further silane hydrolysis due to the absorption of water molecules from the air and their condensation with a release of other water molecules. Although, in the end (after $72 \mathrm{~h}$ ), HPAs remain higher than in the beginning. They are also significantly higher than those obtained for modification in water ( $\mathrm{MH}$ and $\mathrm{AH})$. This indicates lower effectiveness of the modification process due to the highly limited water content in the solvent, which occurred insufficient for full hydrolysis of the silanes applied. Lower HPA for AE indicates higher effectiveness of amino silane as against MTMS. It suggests that more hydrophilic amino groups can be more effective in attracting water molecules from a solvent and the air, providing better conditions for silane hydrolysis. On the other hand, their alkaline nature can create better conditions for silane condensation resulting in higher reactivity with hydroxyls present on MCC surface than MTMS.

Surprisingly, HPA for the sample treated with MTMS (ME) is higher in comparison with untreated MCCE, and even its slight increase upon air-drying can be observed. The presence of ethanol can explain this phenomenon. It

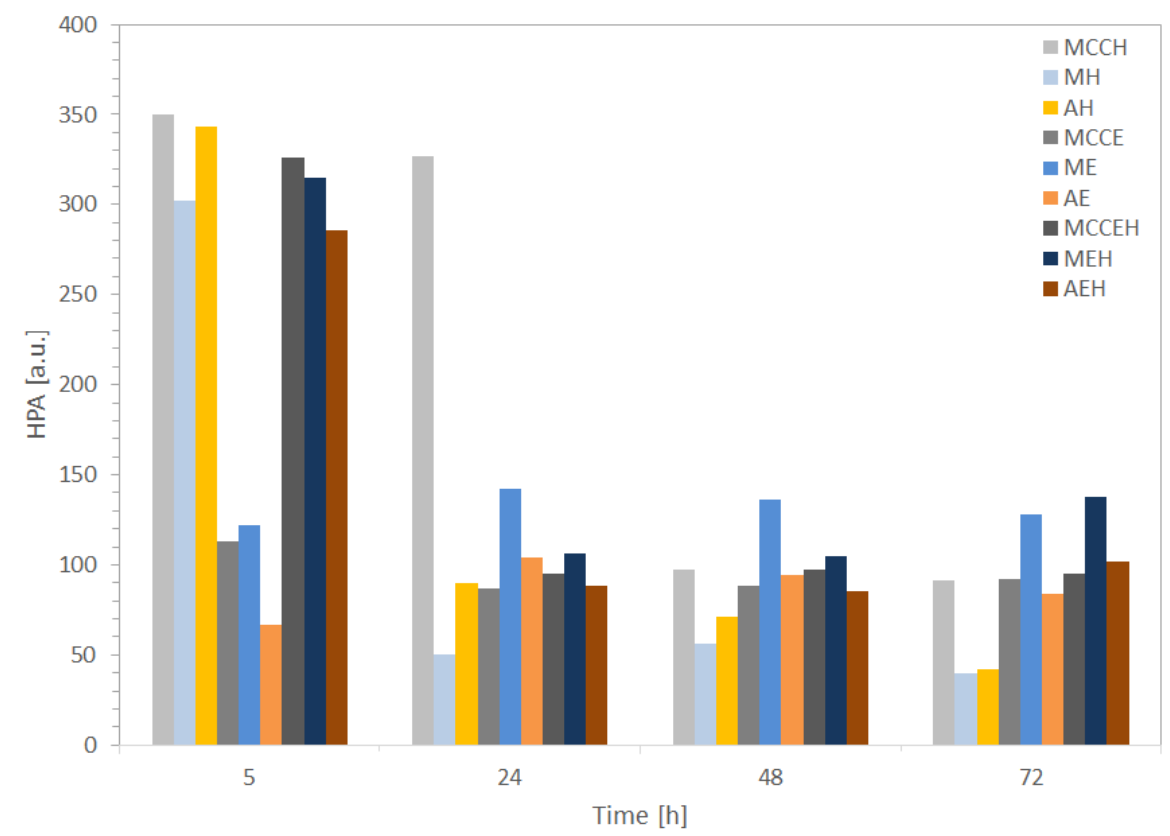

Fig. 4 Changes in hydroxyl peak area (HPA) during air-drying for MCC untreated and silane-treated (mass ratio 1:1) using tested solvents. 
promotes silane hydrolysis leading to the formation of silanols, but simultaneously it inhibits their further condensation. It is possible then that under such conditions, MTMS can hydrolyse using all the available water molecules and bind to cellulose. However, it still contains free hydroxyls connected with silicon atoms $(\mathrm{Si}-\mathrm{OH})$ whose presence can be seen in an infrared spectrum as a band at $3300 \mathrm{~cm}^{-1}$. Free $\mathrm{Si}-\mathrm{OH}$ groups located close to each other can additionally trap water molecules by the formation of hydrogen bonds, and they can add to the intensity of the infrared band specific to hydroxyls. The observed phenomenon indicates lower effectiveness of modification in ethanol than in water. In the case of the samples treated with amino silane, the observed effect is lower, which confirms higher reactivity of this chemical with cellulose.

As can be seen from Figure 4 (MEH, AEH, MC$\mathrm{CEH}$ ), application of an ethanol/water mixture as a solvent resulted in high HPAs shortly after impregnation $(5 \mathrm{~h}$, similarly to the impregnation performed using water only), but also in the highest HPAs after air-drying ( $72 \mathrm{~h}$, comparable with HPAs for samples treated in pure ethanol). The former results from the presence of water molecules in the solvent, the latter suggests that the presence of ethanol promotes silane hydrolysis leading to the formation of silanols, but simultaneously it inhibits further condensation which reflects in lower modification rate (i.e. higher amount of hydroxyls measured). Lower HPA for AEH in comparison with MEH indicates higher effectiveness of amino silane treatment, as described above.

Comparison of the results for all treated samples (Figure 4) can lead to the conclusion that water was definitely the solvent assuring the highest saturation of hydroxyls present on MCC with the applied silanes.

\section{1. 2. Impregnation in Water with a 6-fold Excess of Silanes}

The changes of HPS's of MCC modification with an excess of silanes (mass ratio 1:6) is presented in Figure 5.

When comparing the results for $\mathrm{MH}$ and $\mathrm{MHN}$, it is clear that although $5 \mathrm{~h}$ after silane treatment the HPA is similar for both samples, it differs significantly upon further drying, and after $72 \mathrm{~h}$ it is almost 2.5 times higher for the sample treated with an excess of MTMS. The significantly higher number of free hydroxyls in the MHN sample can result from a higher number of silanols attached only by one $\mathrm{Si}-\mathrm{O}-\mathrm{C}$ bond or by hydrogen bond and two free $\mathrm{Si}-\mathrm{OH}$ groups which can increase HPA.

The different effect of an excess of silane applied can be observed in the case of AEAPTMS-treated samples, where HPA for AHN is continuously lower than for AH during drying. It can be explained by the specific properties of amino groups present in the silane, which promotes silane condensation. As a result, considerably higher effectiveness of MCC modification can be observed than for MHN sample, while in comparison with $\mathrm{AH}$ sample the reactivity with MCC only slightly improved.

\section{1. 3. The Effect of Bound Water on the Number of Hydroxyls Measured and Silanes Reactivity with MCC}

Figure 6 presents the changes in HPAs obtained for MCC samples which were oven-dried, silane-modified, air-dried and then oven-dried again to exclude the effect of bound water on the hydroxyl peak area measured.

When comparing the results for MH and MHS, it is clear that after additional oven-drying HPA increases 2

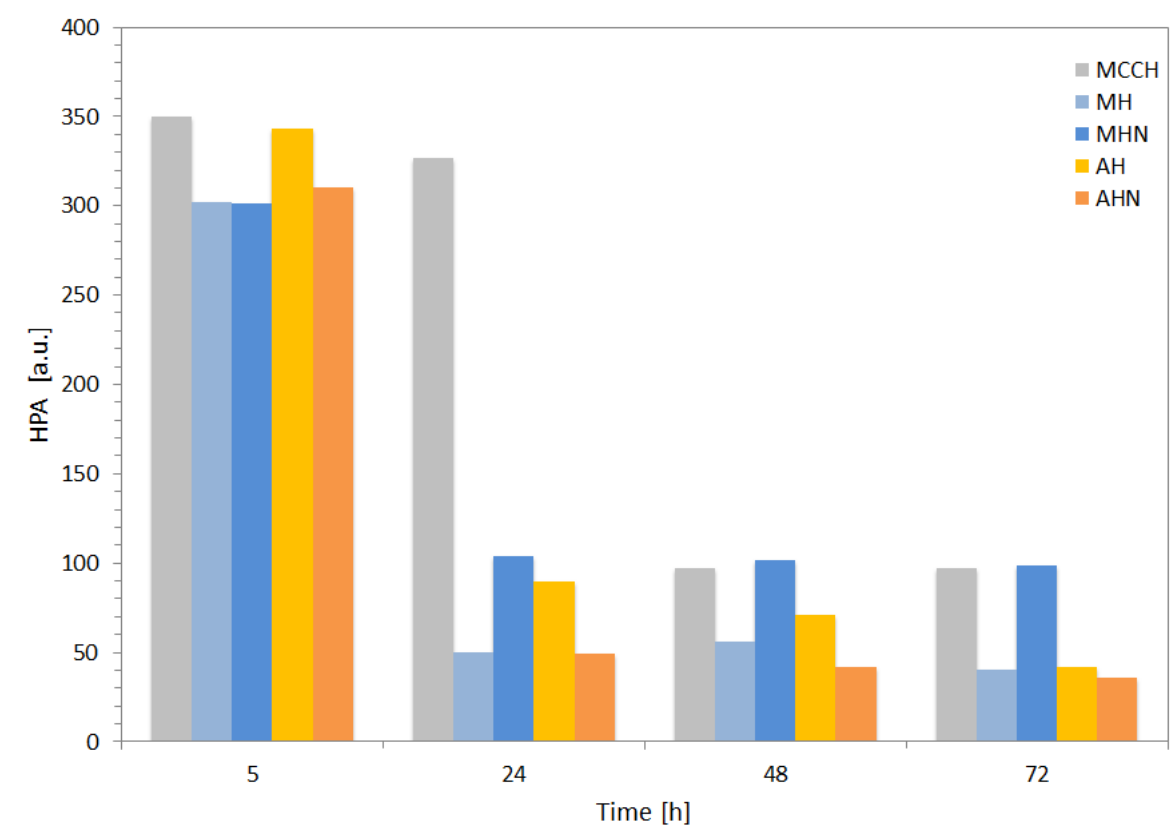

Fig. 5 Comparison of changes in hydroxyl peak area (HPA) during air-drying for MCC treated in water using MCC:silane mass ratio of 1:1 (MH, $\mathrm{AH})$ and 1:6 (MHN, AHN), respectively. 


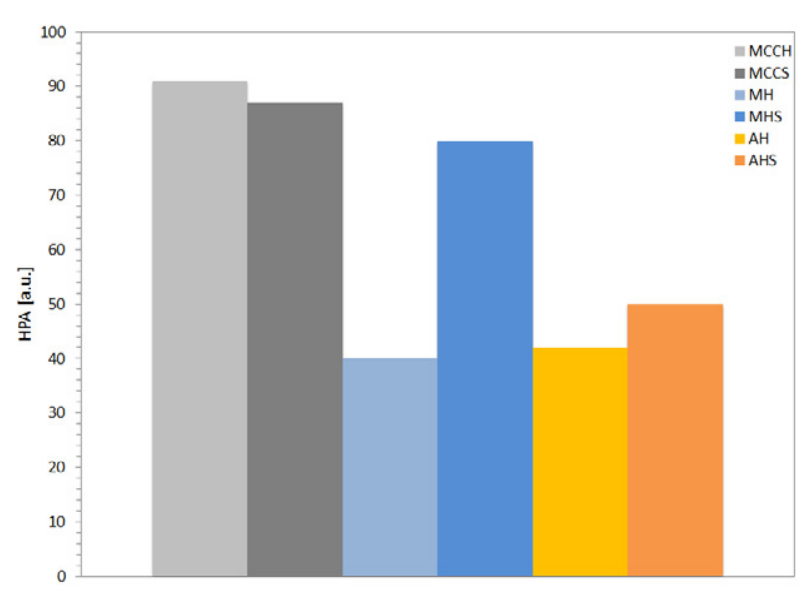

Fig. 6 Changes in hydroxyl peak area (HPA) for unmodified and modified MCC samples after air-drying (MCC, MH, AH) and oven-drying (MCCS, MHS, AHS)

times (from 40 a.u. for MH up to 80 a.u. for MHS) for MHS. The significantly higher number of free hydroxyl groups in the MHS sample can indicate that after hydrolysis of MTMS to a silanol, it only partially binds to MCCS hydroxyls, and the most the formed silanol molecules are attached by hydrogen bonding. The formation of hydrogen bonds results in a decrease of HPAs on infrared spectra what corresponds with the previous results. During drying in $120^{\circ} \mathrm{C}$, hydrogen bonds break and silanols can easily evaporate from the surface (MTMS boiling point $102-104^{\circ} \mathrm{C}$ ). In the case of AEAPTMS the situation is similar, however, an increase in HPA is lower (from 42 a.u. for AH up to 50 a.u. for AHS). The higher $\mathrm{pH}$ of the reaction environment results in a higher condensation rate, which limits the formation of hydrogen bonds and can be the reason for a lower increase of HPA after oven-drying. Besides, because a boiling point for AEAPTMS is at $232^{\circ} \mathrm{C}$, much less of silanol molecules has a chance to evaporate during oven-drying.

\section{1. 4. The Effect of Re-soaking in the Water on Silanes Reactivity with Cellulose}

The influence of re-soaking in the water on silane reactivity with MCC in the form of changes in the hydroxyl peak area (HPA) are presented in Figure 7.

In the first part of the graph (Figure 7), a typical decrease in HPA during air-drying can be seen. The initial high HPA values, resulting from the adsorption of water used as a solvent, are similar for both unmodified and modified MCC. After $48 \mathrm{~h}$ of air-drying, however, a significant difference can be observed between the MCC samples. HPA for treated $\mathrm{MH}$ and $\mathrm{AH}$ is $2 \times$ and $4 \times$ lower than for untreated $\mathrm{MCCH}$, respectively, which confirms their effective modification with silanes.

Air-dried samples (after $48 \mathrm{~h}$ ) were then re-soaked in water for 10 minutes and air-dried again. The effect of re-soaking is clearly visible in Figure 7, since after 24 hours from this point (72 $\mathrm{h}$ on the graph) HPA for MCCH in-

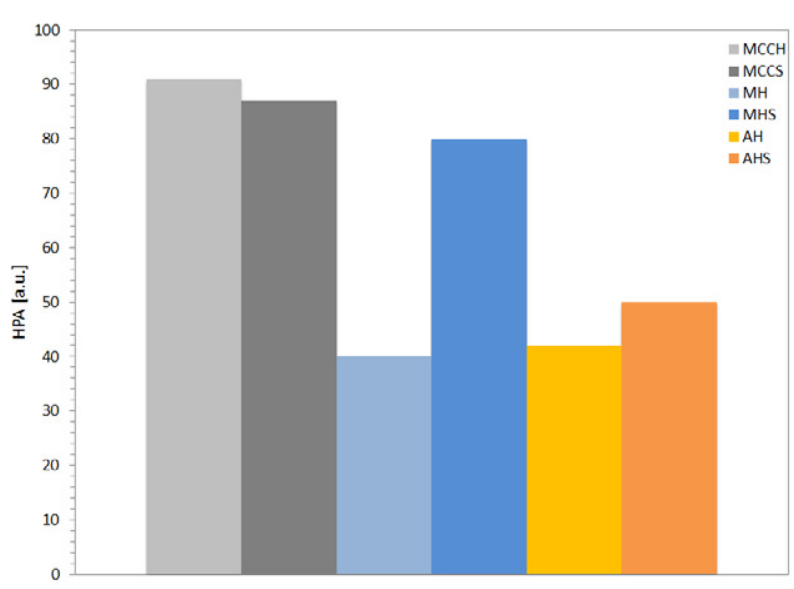

Fig. 7 Effect of re-soaking of unmodified and modified MCC

creased 3,5- (up to 353 a.u.), over 3- for MH (up to 189 a.u.) and 1,5- for $\mathrm{AH}$ (up to 43 a.u.) in comparison with dry samples after $48 \mathrm{~h}$. Further 24-hour drying ( $96 \mathrm{~h}$ on the graph) resulted in a decrease in HPAs, reaching about the same level as before re-soaking for $\mathrm{MCCH}$ and $\mathrm{AH}$ (about 97 a.u. and 31 a.u., respectively) but significantly higher for $\mathrm{MH}$ (81 a.u. after re-soaking versus 58 a.u. before re-soaking, respectively). The observed phenomenon can indicate that a part of MTMS molecules was not chemically bonded with MCC and was washed out during re-soaking, leaving unoccupied hydroxyls on its surface. Another explanation could be that $\mathrm{MH}$ was not completely modified/covered with MTMS; therefore, during re-soaking, water molecules could penetrate the sample. The presence of additional water-induced further polymerisation of the silane which could cover water molecules connected to MCC, so that even after $48 \mathrm{~h}$ of air-drying an increased in HPA originated from water hydroxyls can be observed.

The results of the experiment with re-soaking of the previously treated samples confirmed that MCC modification with MTMS was less efficient than with AEAPTMS. Moreover, it also showed that part of MTMS molecules could be washed out from the modified MCC surface, which means that this type of modification is not permanent.

\section{1 5. Influence of $\mathrm{pH}$ on Silanes Reactivity with Cellulose}

The results of the experiments mentioned above point to the conclusion that the higher effectiveness of AEAPTMS in MCC modification can result from an alkaline reaction environment provided by amino groups present in the silane molecules. Therefore, to find out how alkaline $\mathrm{pH}$ affects silane reactivity with cellulose, the next modification process was carried out in the water with ethylenediamine at $\mathrm{pH}$ adjusted to $10.2(\mathrm{pH}$ level of AEAPTMS solution in water). 


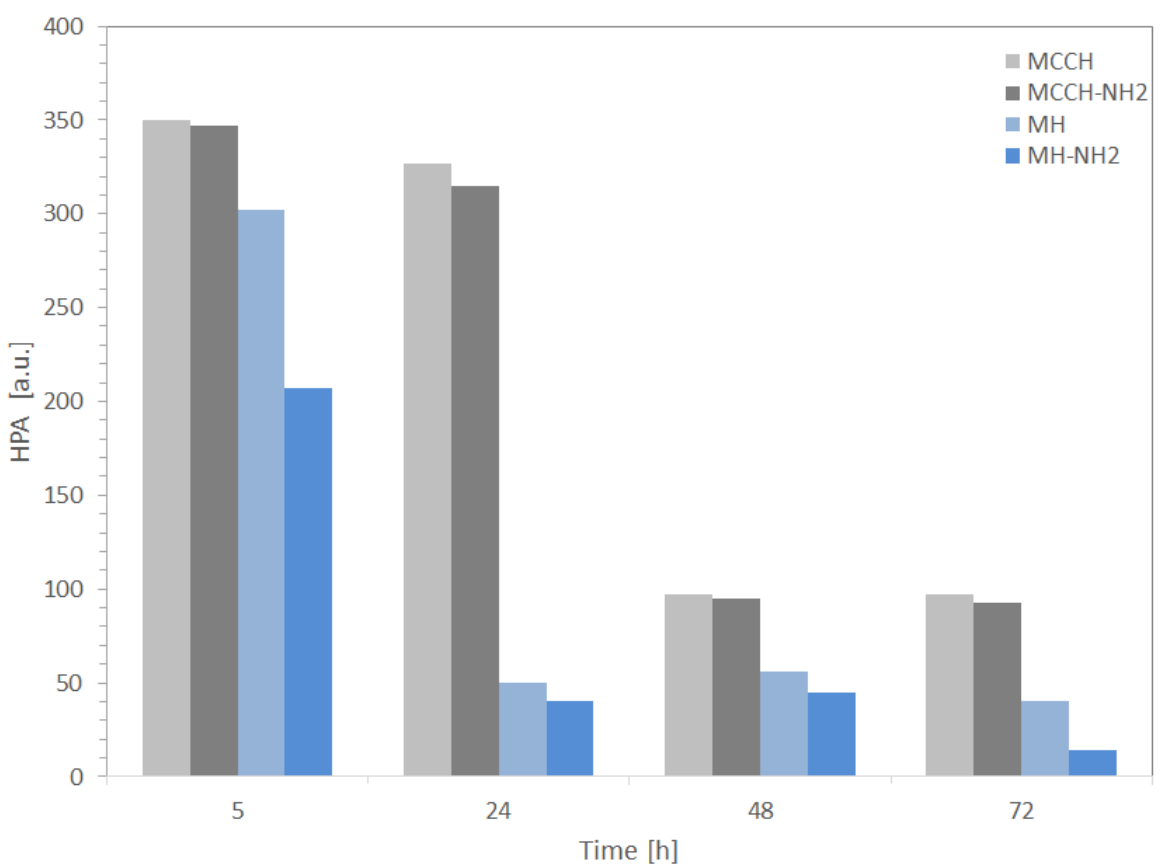

Fig. 8 Comparison of changes in hydroxyl peak area (HPA) during air-drying for MCC treated in water (MH) and water with ethylenediamine $\left(\mathrm{MCCH}-\mathrm{NH} 2, \mathrm{MH}-\mathrm{NH}_{2}\right.$ ), respectively

As can be seen from Figure 8, alkalisation of the reaction environment increased the effectiveness of MCC modification with MTMS which can be seen as a significant decrease in HPA for dry samples from 40 a.u. for MH to 14 a.u. for $\mathrm{MH}-\mathrm{NH}_{2}$. However, the analysis of the FT-IR spectrum in the entire measured range clearly suggests that the addition of ethylenediamine changes the path of the reaction, which can be seen in Figure 8 .
The FT-IR spectra of MCC untreated and treated with MTMS without ethylenediamine (Figure 9) reveal primarily the bands specific to cellulose, i.e. at $3380 \mathrm{~cm}^{-1}$ $(-\mathrm{OH}), 2730 \mathrm{~cm}^{-1}(\mathrm{C}-\mathrm{H}), 1427 \mathrm{~cm}^{-1}\left(-\mathrm{CH}_{2}\right), 1370 \mathrm{~cm}^{-1}$ (C-H), $1315 \mathrm{~cm}^{-1}(-\mathrm{OH})$ as well as $1100 \mathrm{~cm}^{-1}, 1050 \mathrm{~cm}^{-1}$ and $1030 \mathrm{~cm}^{-1}$ (attributed to the stretching of C-O). Additionally, the band at $2960 \mathrm{~cm}^{-1}$ assigned for stretching vibrations of $\mathrm{C}-\mathrm{H}$ and bands at 1260 and $802 \mathrm{~cm}^{-1}$ (at-

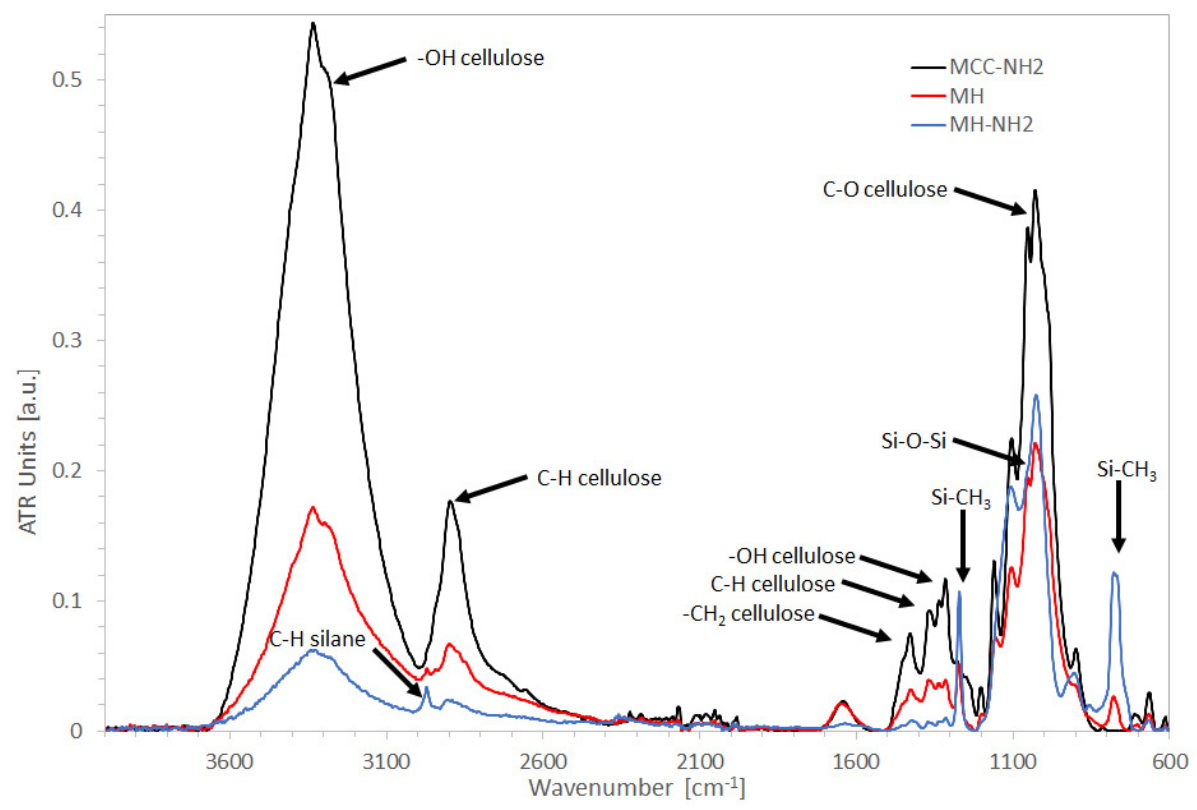

Fig. 9 The FT-IR spectra of $\mathrm{MCCH}, \mathrm{MH}$ and $\mathrm{MH}-\mathrm{NH}_{2}$ 
tributed to the vibrations of $\left.\mathrm{Si}-\mathrm{CH}_{3}\right)$ are present in the $\mathrm{MH}$ spectrum, which indicates the formation of a chemical bond between MTMS and MCC. The spectrum of MCC treated with MTMS in the presence of ethylenediamine, however, looks different. In this spectrum, the bands specific to cellulose at $1427 \mathrm{~cm}^{-1}\left(-\mathrm{CH}_{2}\right), 1370$ $\mathrm{cm}^{-1}(\mathrm{C}-\mathrm{H}), 1315 \mathrm{~cm}^{-1}(-\mathrm{OH})$ cannot be observed, and the band at $2730 \mathrm{~cm}^{-1}(\mathrm{C}-\mathrm{H})$ is significantly decreased. On the other hand, the bands characteristic to silane at $2960 \mathrm{~cm}^{-1}(\mathrm{C}-\mathrm{H})$ as well as at 1260 and $802 \mathrm{~cm}^{-1}$ (attributed to the vibrations of $\mathrm{Si}-\mathrm{CH}_{3}$ ) can be clearly seen. Additionally, a band at $1140-1080 \mathrm{~cm}^{-1}$ takes the shape of the band characteristic to $\mathrm{Si}-\mathrm{O}-\mathrm{Si}$. It can indicate that MTMS-treated MCC in the presence of ethylenediamine is covered/encapsulated by obtained silica instead of being modified by silane.

\section{Conclusions}

The results of the presented research confirm hypothesis that silanes can react with cellulose, whereby the chemical structure of silane molecules affect effectiveness and stability of modification. As was shown, both selected silanes can efficiently modify microcrystalline cellulose. However, treatment with 3-(2-aminoethylamino)propyltrimethoxysilane generally occurred far more effective and durable than with methyltrimethoxysilane, including the reaction using an excess of silanes. It seems that the presence of amino groups in the amino silane molecules enhances its reactivity. On the one hand, it attracts water molecules (e.g. from the moist air) in a water-deficient environment (like ethanol) enabling hydrolysis of silanes; on the other hand, it provides an alkaline reaction environment supporting condensation of silanols, which results in the full polymerisation reaction.

For methyltrimethoxysilane, the results show that the polymerisation reaction may not be complete during MCC treatment and some of the silane molecules may remain in the form of silanols which can form only hydrogen bonds with MCC. This is in line with the results of our previous research when the DVS experiments revealed a similar phenomenon in waterlogged elm treated with MTMS. The full condensation, and thus stabilisation of the silane/wood system was achieved only after 12 cyclic sorption stages. ${ }^{43}$ However, further experiments using waterlogged oak wood did not show such instability of the silane. ${ }^{44}$ These observations are essential from the wood conservation perspective since they all point out that in the case of using a high concentration of MTMS, an additional stage of seasoning the conserved material is necessary to stabilise (fully polymerise) MTMS.

Another result of probable incomplete polymerisation of MTMS is the fact that the silane molecules can be washed out from the modified MCC surface, which means that this type of modification is not permanent. This par- tially confirms the hypothesis that silane treatment can be reversible under particular conditions (presence of water promoting their hydrolysis). However, as was shown, the stability of silane-cellulose interactions depends on the organofunctional group of the silane.

Moreover, in the case of MTMS, an increase in $\mathrm{pH}$ to the level obtained in the reaction with amino silane leads to the encapsulation of microcrystalline cellulose by the silica formed in this reaction rather than to its modification. It suggests that alkaline reaction environment is not the only condition necessary for an effective modification process. The possibility of silica formation seems particularly essential from the conservation perspective. On the one hand, such an inner "skeleton" made of silica inside the wood structure could strengthen or reinforce its mechanical properties, but on the other side, it could also damage the already weakened and decomposed wooden tissue. Therefore, this issue requires further study before the application of silanes could be proposed as an accepted method for waterlogged wood conservation.

The use of dried MCC for modification with silanes decreases its effectiveness, which points out the essential role of bound water in the reaction process.

Among the three tested solvents, the most effective was pure water which assured the highest saturation of hydroxyls present on MCC with the silanes applied. The use of ethanol and a mixture of ethanol and water gave significantly worse results. Additionally, although the presence of ethanol promotes hydrolysis of a silane leading to the formation of silanols, it also simultaneously inhibits their further condensation. From the conservation perspective, these results demonstrate that using ethanol as a solvent will enable penetration of silane monomers into the wooden tissue; however, it should be remembered that the presence of water is necessary for its further polymerisation.

\section{References}

1. S. Kalia, B. Kaith, I. Kaur (Eds.), Cellulose Fibers: Bio- and Nano-polymer Composites: Green Chemistry and Technology. Springer Science \& BusinessMedia, 2011, pp. 97-119.

2. D. Trache, M. H. Hussin, C. T. H. Chuin, S. Sabar, M. N. Fazita, O. F. Taiwo, M. K. Hassan, M. M. Haafiz, Int. J. Biol. Macromol. 2016, 93,789-804.

DOI:10.1016/j.ijbiomac.2016.09.056

3. A. Gholampour, T. Ozbakkaloglu, J. Mater. Sci. 2020, 55, 829892. DOI:10.1007/s10853-019-03990-y

4. H. A. Khalil, A. H. Bhat, A. I. Yusra, Carbohyd. Polym. 2012, 87(2), 963-979. DOI:10.1016/j.carbpol.2011.08.078

5. Y. K. Kim, V. Chalivendra, Natural fibre composites (NFCs) for construction and automotive industries. In Handbook of Natural Fibres, Woodhead Publishing, 2020, pp. 469-498.

6. L. Berglund, Cellulose-based nanocomposites. In: A. K. Mohanty, M. Misra, L. T. Drzal (Eds.), Natural Fibers, Biopolymers, and Biocomposites, CRC Press, 2005, pp. 807-832. 
7. A. Boldizar, C. Klason, J. Kubat, P. Näslund, P. Saha, , Int. J. Polym. Mater. 1987, 11(4), 229-262.

DOI:10.1080/00914038708078665

8. D. de Morais Zanata, L. C. Battirola, M. do Carmo Gonçalves, Cellulose 2018, 25(12), 7225-7238. DOI:10.1007/s10570-018-2090-y

9. R. A. Ilyas, S. M. Sapuan, M. R Ishak, E. S. Zainudin, Carbohyd. Polym. 2018, 202, 186-202.

DOI:10.1016/j.carbpol.2018.09.002

10. J. Yang, C. R. Han, F. Xu, R. C. Sun, Nanoscale 2014, 6(11), 5934-5943. DOI:10.1039/c4nr01214c

11. H. P. S. Khalil, Y. Y. Tye, C. K. Saurabh, C. P. Leh, T. K. Lai, E. W. N. Chong, N. M. Fazita, J. Hafiidz, A. Banerjee, M. I. Syakir, Express Polym. Lett. 2017, 11, 244-265.

DOI:10.3144/expresspolymlett.2017.26

12. S. Parveen, S. Rana, R. Fangueiro, M. C. Paiva, Cement Concrete Comp. 2017, 78, 146-161.

DOI:10.1016/j.cemconcomp.2017.01.004

13. M. Rico, S. Rodríguez-Llamazares, L. Barral, R. Bouza, B. Montero, Carbohyd. Polym. 2016, 149, 83-93.

DOI:10.1016/j.carbpol.2016.04.087

14. A. Chartrand, J. M. Lavoie, M. A. Huneault, J. Appl. Polym. Sci. 2016, 133, 44348. DOI:10.1002/app.44348

15. C. A. Murphy, M. N. Collins, Polym. Composite. 2018, 39(4), 1311-1320. DOI:10.1002/pc.24069

16. S. T. Sundar, M. M. Sain, K. Oksman, Carbohyd. Polym. 2010, 80(1), 35-43. DOI:10.1016/j.carbpol.2009.10.072

17. L. Xiao, Y. Mai, F. He, L. Yu, L. Zhang, H. Tang, G. Yang, J. Mater. Chem. 2012, 22(31), 15732-15739.

DOI:10.1039/c2jm32373g

18. X. Yu, X. Huang, C. Bai, X. Xiong, Environ. Sci. Pollut. R. 2019, 26(32), 32859-32865.

DOI:10.1007/s11356-019-06317-1

19. Y. Dong, J. Liang, Y. Cui, S. Xu, N. Zhao, Carbohyd. Polym. 2018, 197, 183-193. DOI:10.1016/j.carbpol.2018.05.086

20. L. Meng, H. Zhu, B. Feng, Z. Gao, D. Wang, S. Wei, Prog. Org. Coat. 2020, 141, 105540.

DOI:10.1016/j.porgcoat.2020.105540

21. M. Yanilmaz, Y. Lu, J. Zhu, X. Zhang, J. Power. Sources. 2016, 313, 205-212. DOI:10.1016/j.jpowsour.2016.02.089

22. S. Donath, H. Militz, C. Mai, Wood Sci. Technol. 2004, 38(7), 555-566. DOI:10.1007/s00226-004-0257-1

23. D. Levy, M. Zayat (Eds.), The Sol-Gel Handbook, 3 Volume Set: Synthesis, Characterisation, and Applications (Vol. 2). John Wiley \& Sons, 2015, pp. 17-21.

24. D. Panov, N. Terziev, Int. Biodeter. Biodeg. 2009, 63(4),456461. DOI:10.1016/j.ibiod.2008.12.003

25. Y. Xie, C.A. Hill, D. Sun, Z. Jalaludin, Q. Wang, C. Mai, BioResources 2011, 6(3), 2323-2339.

26. H. Abdellaoui, R. Bouhfid, A. E. K. Qaiss, Lignocellulosic fibres reinforced thermoset composites: preparation, characterisation, mechanical and rheological properties. In Lignocellulosic Composite Materials. Springer, Cham. 2018, pp. 215-270. DOI:10.1007/978-3-319-68696-7_5

27. K. L. Mittal, Silanes and other coupling agents. VSP, Leiden, 2009, pp. 51-64.
28. M. S. Sreekala, S. Thomas, Compos. Sci. Technol. 2003, 63(6), 861-869. DOI:10.1016/S0266-3538(02)00270-1

29. Y. Xie, C. A. S. Hill, Z. Xiao, H. Militz, C. Mai, Compos. Part A-Appl. S. 2010, 41(7), 806-819.

DOI:10.1016/j.compositesa.2010.03.005

30. Z. Zhang, G. Sèbe, D. Rentsch, Chem. Mater. 2014, 26, 26592668. DOI:10.1021/cm5004164

31. M. de Oliveira Taipina, M. M. F. Ferrarezi, I. V. P. Yoshida, M. D. C. Gonçalves, Cellulose 2013, 20, 217-226.

DOI:10.1007/s10570-012-9820-3

32. S. Donath, H. Militz, C. Mai, Holzforschung 2006, 60(2), 210216. DOI:10.1515/HF.2006.035

33. R. M. Neves, H. L. Ornaghi Jr, A. J. Zattera, S. C. Amico, Carbohyd. Polym. 2020, 230, 115595.

DOI:10.1016/j.carbpol.2019.115595

34. L. D. Rajapaksha, H. A. D. Saumyadi, A. M. P. B. Samarasekara, D. A. S. Amarasinghe, L. Karunanayake, Development of cellulose based light weight polymer composites. In: 2017 Moratuwa Engineering Research Conference (MERCon). IEEE, 2017, pp. 182-186.

DOI:10.1109/MERCon.2017.7980478

35. M. K. Thakur, R. K. Gupta, V. K. Thakur, Carbohyd. Polym. 2014, 111, 849-855. DOI:10.1016/j.carbpol.2014.05.041

36. M. Wang, T. Yu, Z. Feng, J. Sun, X. Gu, H. Li, B. Fei, S. Zhang, Polym. Advan. Technol. 2020, 1-9. DOI:10.1002/pat.4863

37. M. Fir, J. Vince, A. S. Vuk, A. Vilcnik, V. Jovanovski, G. Mali, B. Orel, B. Simoncic, Acta Chim. Slov. 2007, 144-148.

38. I. Milosev, Acta Chim. Slov. 2019, 511-533. DOI:10.17344/acsi.2019.5162

39. E. Soleimani, N. Zamano, Acta Chim. Slov. 2017, 644-653. DOI:10.17344/acsi.2017.3459

40. N. Demirkiran, E. Ekinci, Acta Chim. Slov. 2012, 302-306.

41. M. Steinbuecher, P. Venturini, J. Hafner, M. Zupancic, P. Gregorcic, I. Golobic, Acta Chim. Slov. 2017, 938-944. DOI:10.17344/acsi.2017.3637

42. M. Broda, I. Dąbek, A. Dutkiewicz, M. Dutkiewicz, C-M. Popescu, B. Mazela, H. Maciejewski, Sci. Rep. 2020, 10(1), 1-13. DOI:10.1038/s41598-020-59240-8

43. M. C. Brochier Salon, M. Abdelmouleh, S. Boufi, M. N. Belgacem, A. Gandini, J. Colloid. Interf. Sci. 2005, 289(1), 249261. DOI:10.1016/j.jcis.2005.03.070

44. M. W. Daniels, L. F. Francis, J. Colloid. Interf. Sci. 1998, 205(1) 191-200. DOI:10.1006/jcis.1998.5671

45. N. Nishiyama, K. Horie, T. Asakura, J. Colloid. Interf. Sci. 1989, 129(1), 113-119.

DOI:10.1016/0021-9797(89)90420-7

46. D. M. Panaitescu, D. Donescu, C. Bercu, D. M. Vuluga, M. Iorga, M. Ghiurea, Polym. Eng. Sci. 2007, 47(8), 1228-1234. DOI:10.1002/pen.20803

47. Z. Olejniczak, M. Leczka, K. Cholewa-Kowalska, K. Wojtach, M. Rokita, W Mozgawa, J. Mol. Struc. 2005, 744, 465-471. DOI:10.1016/j.molstruc.2004.11.069

48. M. Broda, J. Majka, W. Olek, B. Mazela, Int. Biodeter. Biodegr. 2018, 133, 34-41. DOI:10.1016/j.ibiod.2018.06.007

49. M. Broda, S. F. Curling, M. J. Spear, C. A. Hill, Wood Sci. Tech. 2019, 53(3), 703-726. DOI:10.1007/s00226-019-01095-y

Pietras et al.: Reactivity of Microcrystalline Cellulose with Methyltrimethoxysilane ... 


\section{Povzetek}

V tej raziskavi smo uporabili dva trialkoksisilana za študij reaktivnosti z mikrokristalinično celulozo (MCC), ki je bila uporabljena kot modelni material. Kot nadaljevanje prešnje študije je bila raziskava namenjena oceni trajnosti in potencialne reverzibilnosti obdelave s silanom. Za modifikacijo silana smo uporabili dve različni topili in njuno mešanico. Raziskali smo vpliv amino skupin, $\mathrm{pH}$, presežka silana in ponovnega namakanja $\mathrm{z}$ vodo pri vezavi s celulozo. Dobljeni rezultati so potrdili, da lahko oba izbrana silana učinkovito spremenita MCC. Vendar pa je bila obdelava s 3-(2-aminoetilamino)-propiltrimetoksisilanom zaradi prisotnosti amino skupin učinkovitejše kot $\mathrm{z}$ metil-tri-metoksisilanom. Med tremi testiranimi topili je bila najbolj učinkovita čista voda. Uporaba etanola in mešanice etanola in vode pa je, nasprotno, dala bistveno slabše rezultate. Predstavljena raziskava presenetljivo jasno pokaže, kako pomemben za kemijsko reaktivnost $\mathrm{z}$ naravnimi polimeri je tip funkcionalnih skupin $\mathrm{v}$ alkoksisilanih, kar je ključnega pomena za njihovo uporabo pri ohranjanju lesa, zalitega $\mathrm{z}$ vodo. 